\title{
Cervical Myelopathy Caused by Engorgement of the Epidural Venous Plexus due to Cerebrospinal Fluid Overdrainage: Case Report and Review of the Literature
}

\section{Mielopatia cervical causada por ingurgitamento do plexo venoso epidural devido à hiperdrenagem liquórica: relato de caso e revisão da literatura}

\author{
Fernando Luiz Rolemberg Dantas ${ }^{1}$ François Dantas ${ }^{2}$ \\ ${ }^{1}$ Department of Neurosurgery, Biocor Instituto e Instituto Mineiro de \\ Neurocirurgia, Belo Horizonte, MG, Brazil \\ ${ }^{2}$ Medical School, Universidade Federal de Minas Gerais, Belo \\ Horizonte, MG, Brazil
}

Jair Leopoldo Raso ${ }^{1}$ Pedro Moreira Coelho Barroso ${ }^{1}$

Address for correspondence Fernando Luiz Rolemberg Dantas, MD, Departamento de Neurocirurgia, Biocor Instituto e Instituto Mineiro de Neurocirurgia, Belo Horizonte, Minas Gerais, Brazil (e-mail: frdantas@uai.com.br).

Arq Bras Neurocir 2016;35:323-328.

\section{Abstract \\ Keywords \\ - overdrainage \\ - spinal dural enhancement \\ - ventriculoperitoneal shunt \\ - cervical myelopathy \\ - vertebral venous system \\ - craniocervical junction}

\section{Resumo}

This is a case report of a 33-year-old woman with cervical myelopathy caused by an enlargement of the cervical venous plexus, after she was submitted to a ventriculoperitoneal (VP) shunt that evolved to overdrainage.

Magnetic Resonance Imaging (MRI) revealed an epidural venous enlargement within the spinal channel, with a $50 \%$ narrowing from $\mathrm{C} 2$ to $\mathrm{C} 5$, and spinal cord compression. A shunt revision was performed using a programmable drainage system, and a second MRI revealed the absence of the venous enlargement, resulting in cervical spinal cord decompression and remission of neurological symptoms.

Compressive myelopathy consequent to the enlargement of the epidural venous plexus related to the overdrainage of the ventriculoperitoneal shunt system without typical signs of intracranial hypotension may result in misleading etiological diagnoses. Acknowledging this disorder is important to distinguish it from neoplastic processes or hematomas, for which surgical intervention may be needed.

Este é um relato de caso de uma paciente de 33 anos de idade que apresentou mielopatia cervical devido a alargamento do plexo venoso cervical, após ser submetida a uma derivação ventriculoperitoneal que evoluiu com hiperdrenagem. received

May 9, 2016

accepted

June 22, 2016

published online

August 16, 2016
DOI http://dx.doi.org/

10.1055/s-0036-1586240. ISSN 0103-5355.
Copyright $(2016$ by Thieme-Revinter

Publicações Ltda, Rio de Janeiro, Brazil
License terms

(c) $(1) \$$ 


\author{
Palavras-chave \\ - hiperdrenagem \\ - alargamento dural \\ espinhal \\ - derivação \\ ventriculoperitoneal \\ - mielopatia cervical \\ - sistema venoso \\ vertebral \\ - junção craniocervical
}

Exame de Ressonância Nuclear Magnética (RNM) revelou alargamento do plexo venoso epidural no canal espinhal, com estreitamento de $50 \%$ em C2 a C5, e compressão da medula espinhal. Uma revisão da derivação foi feita com um sistema de drenagem programável, e uma segunda RNM revelou ausência de ingurgitamento venoso, resultando em descompressão medular e remissão dos sintomas neurológicos.

Mielopatia compressiva consequente ao alargamento do plexo venoso epidural relacionado à hiperdrenagem do sistema de derivação ventriculoperitoneal sem sinais típicos de hipotensão intracraniana pode resultar em diagnósticos incorretos. O conhecimento dessa patologia é importante para distingui-la de processos neoplásicos ou hematomas, nos quais intervenções cirúrgicas podem ser necessárias.

\section{Introduction}

The typical clinical manifestations of cerebrospinal fluid (CSF) overdrainage include orthostatic headache, nausea, vomiting, neck pain, diplopia and blurred vision. ${ }^{1}$ Brain magnetic resonance imaging (MRI) findings related to spontaneous intracranial hypotension $(\mathrm{SIH})$ are rather variable: diffuse pachymeningeal enhancement associated with pituitary enlargement, optic chiasm flattening, increased anterioposterior diameter of the brainstem, and engorged cerebral venous sinuses may be encountered. Spinal MRI revealing an extraarachnoid fluid collection, extradural extravasation of fluids, meningeal diverticula, diffuse pachymeningeal enhancement, and enlargement of the spinal epidural venous plexus are not uncommon, ${ }^{2}$ but compressive cervical myelopathy related to the epidural venous plexus engorgement caused by fluid hypotension is extremely rare. ${ }^{3-11}$

This paper reports the case of a patient who presented a progressive cervical myelopathy related to an epidural venous plexus engorgement caused by shunt overdrainage. Since an early diagnosis was never reached, this case report covers the primary findings and pitfalls before the primary etiology was revealed.

\section{Case Report}

Case history: A 33-year-old woman was admitted to our service presenting a two year history of clinical cognitive progressive deficit, associated with visual alterations, episodes of loss of strength in the upper right limb, weakness in the lower limbs, and urinary retention. Both brain MRI and computed tomography (CT) exams revealed a communicating hydrocephalus associated with cortical atrophy (-Fig. 1). Routine blood tests detected anemia, under only the hematological evaluation, thus the apparent cause of the anemia was not encountered.

The patient was submitted to a ventriculoperitoneal (VP) shunt with a high-pressure system. She developed a headache, which improved in repose, and control CT scans showed a well-positioned valve with reduction of the ventricular cavity.

Approximately two years after the VP shunt implant was done, neck pain, headache and visual deficit worsened, accompanied by quadriparesis and paresthesia.

A cervical MRI evidenced the presence of an anterior cervical mass leading to significant spinal cord compression (-Fig. 2), and a brain MRI showed the absence of
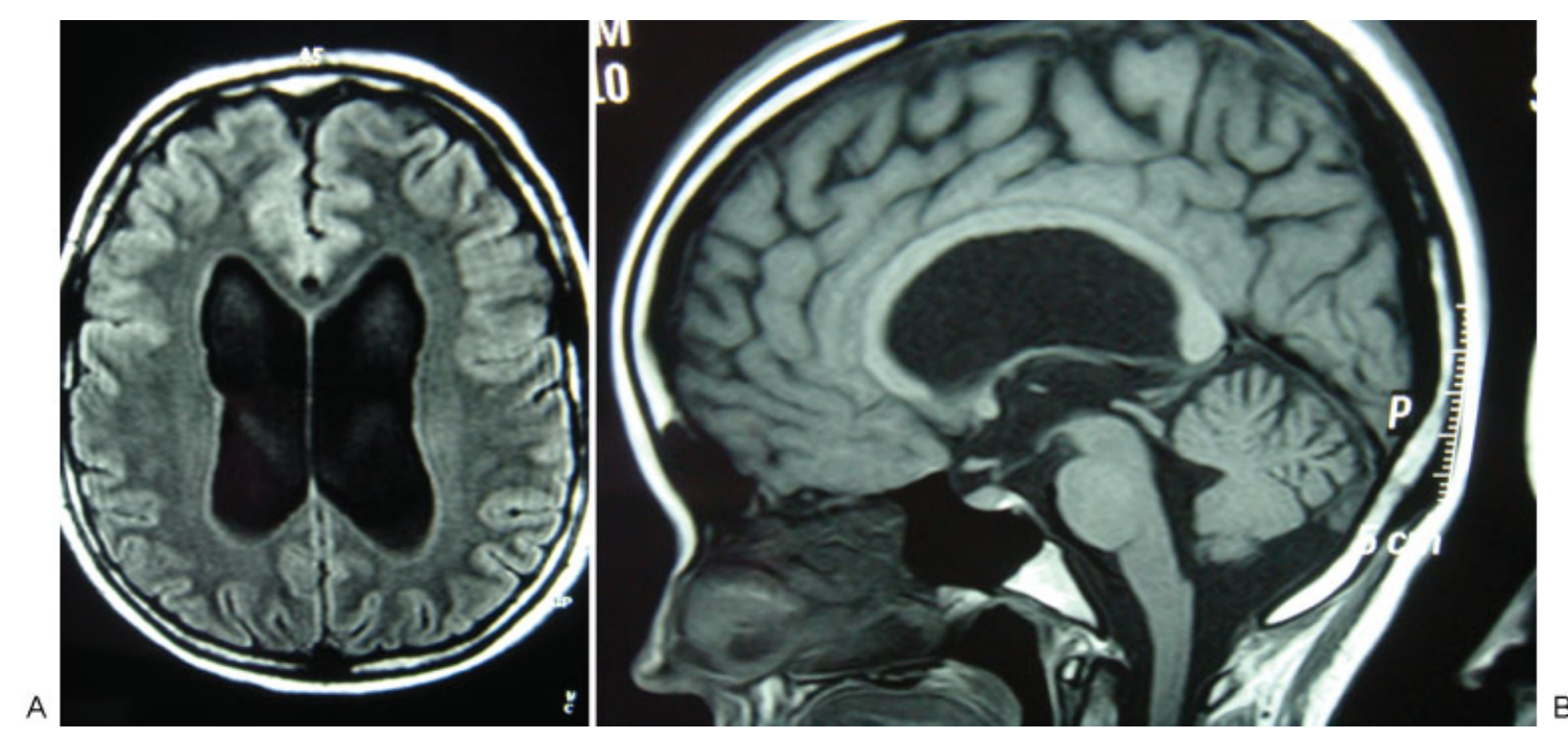

Fig. 1 Axial (A) and sagittal (B) T1-weighted MRI revealing a communicating hydrocephalus. 


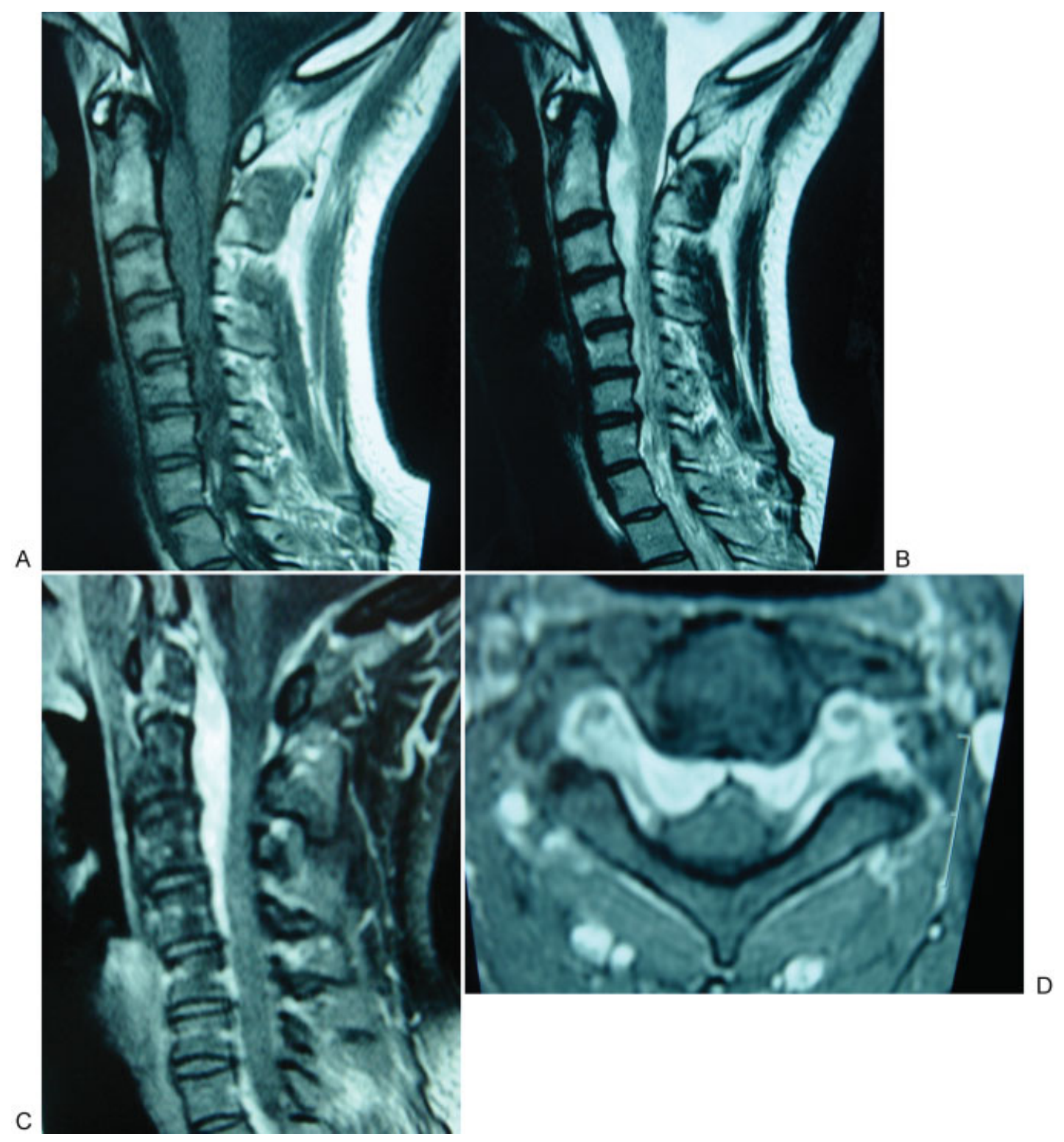

Fig. 2 MRI images of the cervical spine two years after the VP shunt. T1-weighted (A), T2-weighted (B) and gadolinium-enhanced T1-weighted (C, D) demonstrating spinal cord compression at C2-C5.

hydrocephalus. Angioresonance showed a significant enlargement of the epidural venous plexus (-Fig. 3). The VP shunt overdrainage hypothesis had not been considered until then.

In another service, the patient was submitted to the replacement of the shunt system by a programmable pressure valve, and evolved to a progressive improvement in the neurological symptoms.

The control cervical MRI at one year revealed the complete absence of the cervical epidural mass (-Fig. 4).

\section{Discussion}

Venous drainage at the craniocervical junction flows through the internal jugular vein and vertebral veins with contribution of their associated anastomoses. The anterior and posterior condylar veins form the plexus of the vertebral vein, but this may be modified by the presence of emissary anastomoses of the mastoid, with an increased possibility of drainage at this level. The veins of the junction are formed by the confluence of the emissary and posterior cephalic veins with the superior epidural venous system. ${ }^{12}$

The contribution of the internal jugular veins for cerebral drainage is variable among individuals, with a possible venous flow ranging all the way from 6 to $72 \%{ }^{13}$ The epidural cervical venous system is located in the anterolateral portion of the spinal channel, and it may function as an alternative to the cranial drainage system, possibly affecting the intracranial pressure in some cases. It is equivalent to an independent accessory venous drainage system of the intracranial compartment.

The vertebral venous system may be divided into anterior and posterior sections, respectively consisting of the intraspinal epidural venous plexus and the external posterior paravertebral 


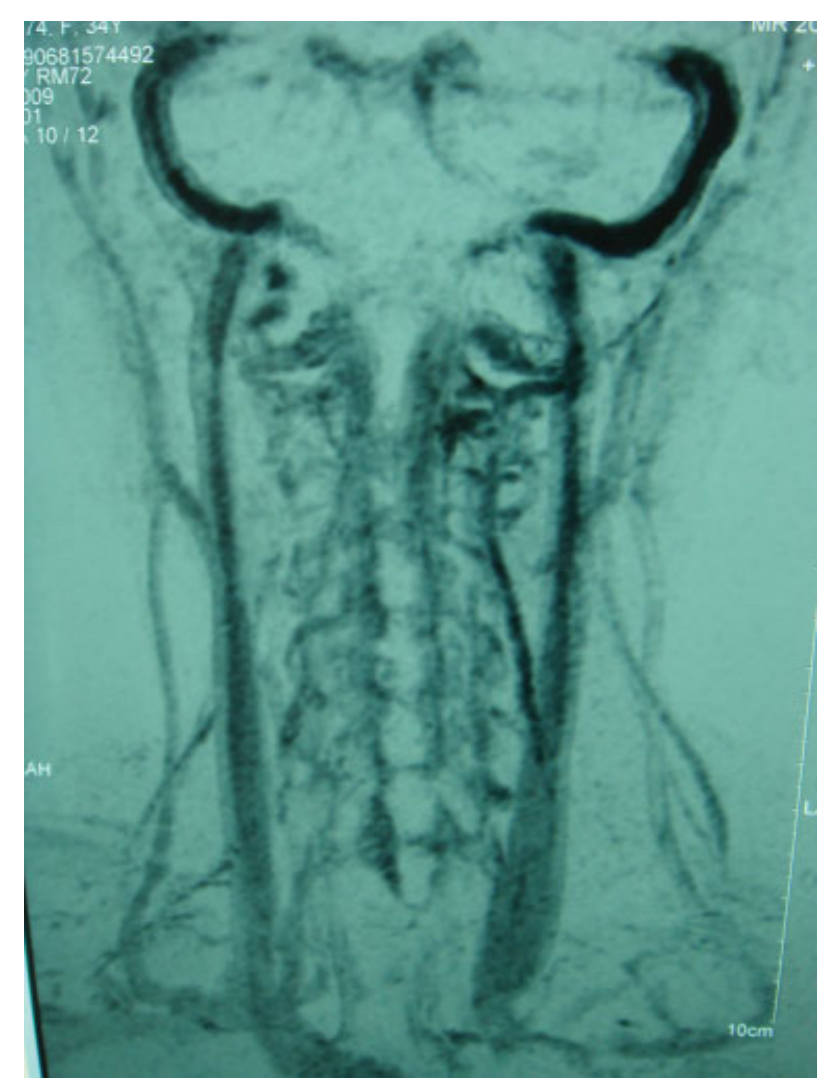

Fig. 3 Cervical angioresonance demonstrating internal vertebral venous plexus engorgement, especially of the anterior compartment. system. ${ }^{14}$ Functional variations may occur depending on the flexion or extension and position of patient's head.

Intracranial hypotension syndrome is characterized by postural headache and low fluid pressure. It may be classified into five types: primary or spontaneous; post lumbar puncture; cranial post-trauma; post-craniotomy; and severe depletion of volume. Ventriculoperitoneal shunt overdrainage is also thought to be another cause of intracranial hypotension syndrome. $^{15}$

Schaltenbrand ${ }^{16,17}$ introduced the concept of SIH and proposed three mechanisms to explain its pathophysiology: 1) decreased CSF production; 2) CSF hyperabsorption; or 3) CSF leak.

Spinal manifestations of SIH occur in nearly $6 \%$ of patients, and may involve all spinal levels with either myelopathy or radiculopathy. Diagnosis is not only difficult; in many cases, it is also late, given the infrequent spinal image evaluation, not counting the fact that nearly $20 \%$ of brain MRIs present as normal. ${ }^{18}$ Findings on brain MRI regarding SIH are variable. Diffuse pachymeningeal enhancement; pituitary enlargement; increased antero-posterior diameter of brainstem; subdural fluid collection; and engorged cerebral venous sinuses may be observed. Extra-arachnoid fluid collection, extradural extravasation of fluid, meningeal diverticula, diffuse pachymeningeal enhancement, and engorgement of the spinal epidural venous plexus may be noted in the spinal MRI. $^{2}$

The diffuse dural enhancement is considered to be the result of venous dilation caused by low CSF volume. According to what Monro-Kellie advocates, the intracranial volume
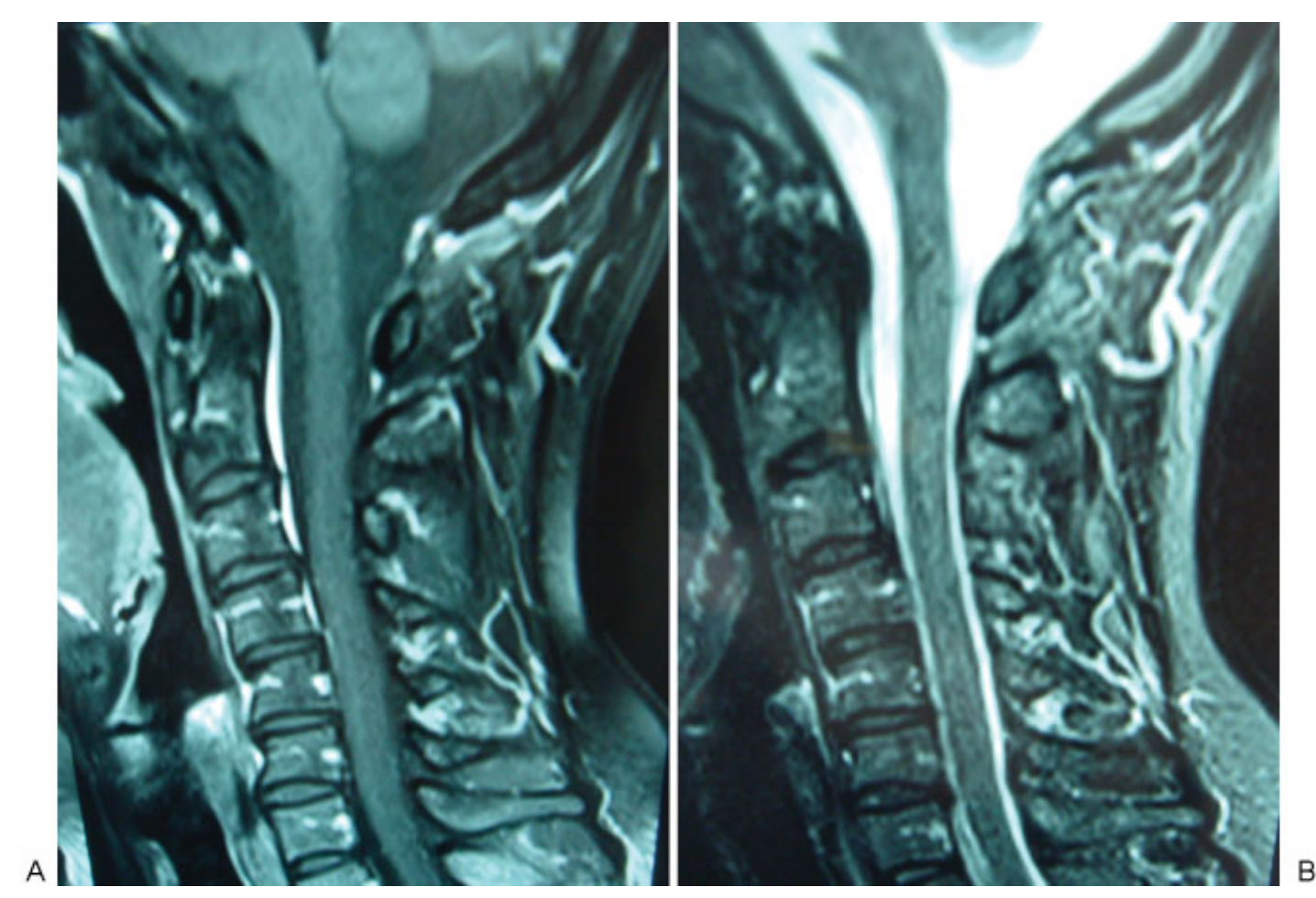

Fig. 4 Sagittal cervical T1-weighted (A) and T2-weighted (B) MRI one year after surgery, demonstrating no spinal cord compression and no engorgement of the cervical venous plexus. 
of CSF is inversely related to the cerebral blood volume. For this reason, in SIH cases, a decreased CSF volume leads to an increase in the dural venous blood volume and consequent venous enlargement. ${ }^{19}$ This mechanism results in dural thickening and enhancement. The Monro doctrine may be applied to the vertebral channel, as both cavities, cranial and spinal, are closed systems. 8,20

Förderreuther et al were able to demonstrate through cervical MRI the cervical epidural veins' dilation during orthostatic headache crises, with subsequent improvement and remission of those signs once the pain subsided. ${ }^{20}$ Ciceri showed evidence of vein dilation in Hirayama myelopathy cases. ${ }^{21}$ The epidural venous plexus engorgement has been described as another cause of radicular compression, ${ }^{22-24}$ and $\mathrm{SIH}$ was also shown to be a cause of dilation of the epidural venous plexus. ${ }^{1}$

In an extensive review of the literature, not more than 10 related cases have been found - this present case included - where a cervical venous plexus engorgement results from shunt overdrainage (-Table 1). In 1998, Miyazaki et al were the first to describe the clinical manifestation of myelopathy in the overdrainage of a VP shunt system in a patient with a low-pressure shunt after subarachnoid hemorrhage. ${ }^{8}$ In the cases described, the time interval to the onset of overdrainage symptoms after shunt placement was quite variable. An interesting observation regards the initial manifestations of myelopathy, which varied from 4 months to 10 years. $^{3}$

Also noteworthy is the fact that no cases described in the literature have presented the classic symptoms of CSF overdrainage. The majority of patients have presented with motor deficit clinical symptoms (9 cases), and only 1 case presented with neck and back pain. ${ }^{6}$ The present case initially presented with headache, which improved in repose, and with neck pain after light trauma, further evolving into the known fluid hypotension and compressive cervical myelopathy symptoms.

Surgical treatment was needed in eight cases. Shunt system replacement was the most common occurrence, and clinical improvement was observed in all cases after surgery. There was one case in which treatment was refused, ${ }^{11}$ and another patient who only underwent clinical follow-up. ${ }^{6}$ Complications such as the above mentioned illustrate a rare clinical presentation of VP shunt failure, reinforcing that adequate knowledge of this pathology is paramount to its early identification.

Table 1 Cases described in the literature and results

\begin{tabular}{|c|c|c|c|c|c|c|}
\hline Literature & $\begin{array}{l}\text { Sex/ } \\
\text { Age }\end{array}$ & Pathology & $\begin{array}{l}\text { Symptoms/ } \\
\text { time after VP } \\
\text { shunt }\end{array}$ & $\begin{array}{l}\text { Radiological } \\
\text { findings }\end{array}$ & Treatment & Results \\
\hline $\begin{array}{l}\text { Miyazaki } \\
\text { et } \mathrm{al}^{8}\end{array}$ & $\mathrm{M} / 53$ & SAH & Quadriparesis/ & $\begin{array}{l}\text { Spinal cord com- } \\
\text { pression CCJ-C3 }\end{array}$ & $\begin{array}{l}\text { Ligation of VP } \\
\text { shunt }\end{array}$ & Improvement \\
\hline $\begin{array}{l}\text { Matsumoto } \\
\text { et al }\end{array}$ & $\mathrm{M} / 67$ & Pineal tumor & $\begin{array}{l}\text { Paraparesis/ } \\
2 \text { years }\end{array}$ & $\begin{array}{l}\text { Cranial diffuse men- } \\
\text { ingeal enhancement }\end{array}$ & $\begin{array}{l}\text { Removal of the } \\
\text { shunt }\end{array}$ & Improvement \\
\hline $\begin{array}{l}\text { Wingerchuk } \\
\text { et al }\end{array}$ & $F / 72$ & $\begin{array}{l}\text { Posterior fossa } \\
\text { meningioma }\end{array}$ & Quadriparesis/ & $\begin{array}{l}\text { Cervical } \\
\text { enhancement }\end{array}$ & $\begin{array}{l}\text { Refused } \\
\text { treatment }\end{array}$ & Unchanged \\
\hline Liu et al $^{5}$ & $F / 18$ & $\begin{array}{l}\text { Porencephalic } \\
\text { cyst }\end{array}$ & $\begin{array}{l}\text { Quadriparesis/ } \\
4 \text { months }\end{array}$ & $\begin{array}{l}\text { Engorgement of the } \\
\text { epidural veins }\end{array}$ & $\begin{array}{l}\text { Change to pro- } \\
\text { grammable shunt }\end{array}$ & Improvement \\
\hline $\begin{array}{l}\text { Humphries } \\
\text { et al }\end{array}$ & $F / 33$ & Dandy-Walker & $\begin{array}{l}\text { Paraparesis/ } \\
\text { - }\end{array}$ & $\begin{array}{l}\text { Engorgement of the } \\
\text { epidural C2-C5 }\end{array}$ & Change revision & Improvement \\
\hline Wolfe et $a^{10}$ & $\mathrm{M} / 17$ & Tumor cyst & $\begin{array}{l}\text { Quadriparesis/ } \\
5 \text { years }\end{array}$ & $\begin{array}{l}\text { Dilated epidural } \\
\text { venous plexus }\end{array}$ & $\begin{array}{l}\text { Change to pro- } \\
\text { grammable shunt }\end{array}$ & Improvement \\
\hline $\begin{array}{l}\text { Martínez-Lage } \\
\text { et al }\end{array}$ & $F / 20$ & $\begin{array}{l}\text { Communicating } \\
\text { hydrocephalus }\end{array}$ & $\begin{array}{l}\text { Neck and } \\
\text { back pain/ } \\
\text { - }\end{array}$ & $\begin{array}{l}\text { Lesion mimicking } \\
\text { cervical epidural } \\
\text { hematoma C1-C5 }\end{array}$ & $\begin{array}{l}\text { No surgical } \\
\text { treatment }\end{array}$ & Improvement \\
\hline Ulrich et $\mathrm{al}^{9}$ & $F / 17$ & $\begin{array}{l}\text { Obstructive } \\
\text { hydrocephalus }\end{array}$ & $\begin{array}{l}\text { Paraparesis/ } \\
4 \text { years }\end{array}$ & $\begin{array}{l}\text { Engorgement of the } \\
\text { cervical epidural } \\
\text { venous plexus C2-C3 }\end{array}$ & $\begin{array}{l}\text { Change to anti-si- } \\
\text { phon device, valve } \\
\text { pressure } \\
\text { increased }\end{array}$ & Improvement \\
\hline Cardoso et $\mathrm{al}^{3}$ & $M / 32$ & $\begin{array}{l}\text { Communicating } \\
\text { hydrocephalus }\end{array}$ & $\begin{array}{l}\text { Quadriparesis/ } \\
10 \text { years }\end{array}$ & $\begin{array}{l}\text { Engorgement of the } \\
\text { cervical venous } \\
\text { plexus }(C) \text { and } \\
\text { intracranial }\end{array}$ & $\begin{array}{l}\text { Change to pro- } \\
\text { grammable shunt }\end{array}$ & Improvement \\
\hline $\begin{array}{l}\text { Dantas et al } \\
\text { (present } \\
\text { study) }\end{array}$ & $F / 33$ & $\begin{array}{l}\text { Communicating } \\
\text { hydrocephalus }\end{array}$ & $\begin{array}{l}\text { Quadriparesis/ } \\
2 \text { years }\end{array}$ & $\begin{array}{l}\text { Spinal cord com- } \\
\text { pression by en- } \\
\text { gorgement of the } \\
\text { cervical venous plex- } \\
\text { us C2-C5 }\end{array}$ & $\begin{array}{l}\text { Change to pro- } \\
\text { grammable shunt }\end{array}$ & Improvement \\
\hline
\end{tabular}

Abbreviations: CCJ, craniocervical junction; F, female; M, male; SAH, spontaneous subarachnoid hemorrhage; VP, ventriculoperitoneal. 


\section{Conclusion}

This case is an interesting presentation of clinical failure of the shunt, with overdrainage involving the cervical venous plexus and venous cerebral drainage. The engorgement of the cervical venous plexus should always be kept in mind during differential diagnoses of myelopathy in patients with shunt and clinical signs of overdrainage.

\section{Disclosure}

The authors report no conflicts of interest concerning the materials or methods used in this study or the findings specified in this paper.

\section{Acknowledgments}

The authors wish to express their gratitude to Marina Salim Dantas, Larissa Benevides and José Carlos Martins, MD, for their assistance.

\section{References}

1 Nakahara K, Iida H, Mitomi T, et al. Dilation of spinal epidural veins caused by spontaneous intracranial hypotension: case report. Neurol Med Chir (Tokyo) 2005;45:404-406

2 Mokri B. Low cerebrospinal fluid pressure syndromes. Neurol Clin 2004;22:55-74

3 Cardoso MM, Gepp RA, Quiroga MRS, Sousa HC. Compressão medular decorrente de hiperdrenagem de derivação ventriculoperitoneal: uma rara complicação. Arq Bras Neurocir 2014; 33:85-88

4 Humphries WE, Grossi PM, Liethe LG, George TM. Ventriculoperitoneal shunt failure causing myelopathy in a patient with bilateral jugular vein occlusion. Case report. J Neurosurg Spine 2007;6:60-63

5 Liu JK, Gottfried ON, Brockmeyer DL. Epidural venous engorgement resulting in progressive cervical myelopathy from shuntrelated intracranial hypotension. Case report and review of the literature. J Neurosurg 2006;105:499-503

6 Martínez-Lage JF, Alarcón F, Alfaro R, Ruíz-Espejo A, López-Guerrero AL, Hernández-Abenza J. Cervical extramedullary mass lesion due to chronic CSF overshunting: case report and literature review. Childs Nerv Syst 2009;25:895-898

7 Matsumoto K, Ohta M, Takeshita I. Symptomatic spinal extramedullary mass lesion secondary to chronic overdrainage of ventricular fluid-case report. Neurol Med Chir (Tokyo) 2002; 42:140-142
8 Miyazaki T, Chiba A, Nishina H, Uesaka Y, Nakase H, Kanazawa I. Upper cervical myelopathy associated with low CSF pressure: A complication of ventriculoperitoneal shunt. Neurology 1998; 50:1864-1866

9 Ulrich NH, Maier M, Bernays RL, Krayenbuhl N, Kollias S. Cervical myelopathy due to chronic overshunting in a pediatric patient. Turk Neurosurg 2013;23:410-414

10 Wolfe SQ Bhatia S, Green B, Ragheb J. Engorged epidural venous plexus and cervical myelopathy due to cerebrospinal fluid overdrainage: A rare complication of ventricular shunts. Case report. J Neurosurg 2007;106:227-231

11 Wingerchuk DM, Patel NP, Patel AC, Dodick DW, Nelson KD. Progressive cervical myelopathy secondary to chronic ventriculoperitoneal CSF overshunting. Neurology 2005;65:171-172

12 Braun JP, Tournade A. Venous drainage in the craniocervical region. Neuroradiology 1977;13:155-158

13 Doepp F, Schreiber SJ, von Münster T, Rademacher J, Klingebiel R, Valdueza JM. How does the blood leave the brain? A systematic ultrasound analysis of cerebral venous drainage patterns. Neuroradiology 2004;46:565-570

14 Batson OV. Anatomical problems concerned in the study of cerebral blood flow. Fed Proc 1994;3:139-144

15 Bell WE, Joynt RJ, Sahs AL. Low spinal fluid pressure syndromes. Neurology 1960;10:512-521

16 Schaltenbrand G. Neuere Anschauungen zur Pathophysiologie der Liquorzirkulation. Zbl Neurochir 1938;3:290-295

17 Schaltenbrand G. Normal and pathological physiology of the cerebrospinal fluid circulation. Lancet 1953;1:805-808

18 Schievink WI, Chu RM, Maya MM, Johnson JP, Cohen HC. Spinal manifestations of spontaneous intracranial hypotension. J Neurosurg Spine 2013;18:96-101

19 Mokri B. The Monro-Kellie hypothesis: applications in CSF volume depletion. Neurology 2001;56:1746-1748

20 Förderreuther S, Yousry I, Empl M, Straube A. Dilated cervical epidural veins and extra arachnoid fluid collection in orthostatic headaches. Neurology 2001;57:527-529

21 Ciceri EF, Chiapparini L, Erbetta A, et al. Angiographically proven cervical venous engorgement: a possible concurrent cause in the pathophysiology of Hirayama's myelopathy. Neurol Sci 2010; 31:845-848

22 Albayram S, Wasserman BA, Yousem DM, Wityk R. Intracranial hypotension as a cause of radiculopathy from cervical epidural venous engorgement: case report. AJNR Am J Neuroradiol 2002; 23:618-621

23 Paksoy Y, Gormus N. Epidural venous plexus enlargements presenting with radiculopathy and back pain in patients with inferior vena cava obstruction or occlusion. Spine 2004;29:2419-2424

24 Pennekamp PH, Gemünd M, Kraft CN, von Engelhardt LV, Lüring C, Schmitz A. Epidural varicosis as a rare cause of acute radiculopathy with complete foot paresis-case report and literature review. Z Orthop Ihre Grenzgeb 2007;145:55-60 